\title{
Blended Learning Model Design Integrated with Problem Based Learning and Rehearsal Pairs Practice to Increase Motivation and Outcomes in Marketing Management Course
}

\author{
Ludfi Djajanto*, Indrayati, Suryadi \\ Accounting Department \\ State Polytechnic of Malang \\ Malang, Indonesia \\ *ludfimlg@yahoo.com, indrayati@polinema.ac.id, suryadipolinema@yahoo.com
}

\begin{abstract}
In the era of industrial revolution 4.0, the use of technology and the internet was almost implemented in all fields including education, especially in the learning process. The use of information technology in learning becomes a necessity because it facilitates students and lecturers in carrying out the learning process. This study aims to design an integrated Blended Learning model with Problem Based Learning and Practice Rehearsal Pairs to increase motivation and learning outcomes in the Marketing Management course. Besides, this study also examines the effect of implementing an integrated blended learning model on student motivation and achievement in learning outcomes. The research method used is the development method and classroom action research using a purposive sampling technique for 182 students who took the Marketing Management courses in the data analysis technique used descriptive and inferential statistical analysis. The results showed that there were significant differences between conventional learning and blended learning. Nearly all respondents agree that the blended learning model is more interesting and efficient when it is applied in learning. Besides, the results of hypothesis testing prove that the Blended Learning model integrated with Problem Based Learning and Rehearsal Pairs Practice has a positive and significant effect on increasing motivation and learning outcomes in the Marketing Management course.
\end{abstract}

Keywords - blended learning model; problem based learning; rehearsal pair practice; motivation; learning outcomes; marketing management

\section{INTRODUCTION}

Currently, the development of technology and science is related to the industrial revolution 4.0, one of which is shown by the use of technology and the internet in almost all fields including education. This is because technology and the internet make it easier for people to do work and activities of daily life. The use of technology that combines the physical and digital worlds will fundamentally change the pattern of human life and interaction [1]. Besides, by entering the era of the industrial revolution 4.0, there will be a merger between digital and physical domains based on Cyber-Physical Systems [2]. In the world of education, technological developments and the increasing number of people using the internet will directly affect the need to improve the quality of learning. In facing this industrial era 4.0, it is important to make fundamental changes in the education process so that later college graduates can compete in the world of work. The development of the industrial revolution 4.0 has made it easier for humans to carry out their work activities because most $(75 \%)$ of all current activities already use technology and the internet, including in learning [3].

The use of technology in learning is currently needed such as gadgets, smartphones, and androids can be used as media that can make it easier for students to learn independently in mastering a concept [4]. Besides, the use of information technology in carrying out learning is a necessity because it makes it easier for students and lecturers to carry out learning that is not limited to space and time [5]. This is supported by the use of the internet in learning which will enable students to obtain the latest knowledge and information [6]. A paradigm shift in learning in the 21 st century demands a change in thinking, namely that students can have high order thinking skills (HOTS) critical thinking skills, find solutions, be creative, innovate, communicate, collaborate, and have information and media skills [7, 8].

In vocational education such as polytechnic education, skills are highly demanded to be better prepared to face the world of work. At present, especially in the Marketing Management course at Malang State Polytechnic, there are still many lecturers who use the learning method with the lecture method in the classroom so that it can be categorized as Teacher-Centered Learning (TCL). This situation becomes a problem because the ability of students in general in the field of skills is lacking and there is still low interest and readiness of students in learning because with the lecture method students tend to be less active and more listening. For this reason, to improve student motivation and ability in learning, it is 
necessary to change the learning model, one of which is to use the blended learning model.

In the application of the blended learning model, face-toface learning is combined with e-learning. Blended learning is a new concept in learning where material delivery can be done in class and on-line [9]. The blended learning method which is accompanied by the enrichment of several kinds of learning methods that require active students and critical thinking will turn it into student-centered learning or often known as Student-Centered Learning (SCL). The SCL learning method that can be integrated into the blended learning model includes problem based learning accompanied by practice rehearsal pairs. The learning with a problem-based learning approach (problem-based learning) has been widely carried out in vocational education environments in various universities [10]. Apart from aiming at improving the professionalism of graduates, it is also a form of responsiveness to the emergence of the $21^{\text {st }}$-century learning paradigm. In addition, the practice rehearsal pairs method is one of the methods derived from cooperative learning (active learning) which invites students to learn actively in finding main ideas from the learning material, solving problems, or applying what they have just learned [11].

Previous research found that the application of blended learning was able to positively influence learning outcomes [12]. In addition, Usman [13] found that the blended learning method was able to improve the quality and quality of learning and was able to increase the motivation, interest and learning outcomes of students. There was also a fairly high difference between conventional learning and blended-based learning and the application of blended learning could improve student learning outcomes as well as satisfaction and efficiency [14]. Likewise, research conducted by Prawoto and Pramulia [15] found that the application of blended learning will be able to stimulate and foster learning motivation for students and can improve learning outcomes because of the tendency of students to be more active, innovative, creative, and enthusiastic in independent learning.

Based on previous research and current problems, this research found the novelty because previous research had not yet integrated the blended learning method with the problembased learning method and practice rehearsal pairs. In this study, a blended learning learning method design integrated with problem-based learning and practice rehearsal pairs will be made where for e-learning using Learning Management System (LMS) Moodle while face-to-face uses several variations of learning methods that are adjusted to the topic of discussion by prioritizing students to be active, think critically, and independently.

\section{METHODS}

Types of this research are the development or design of a blended learning model and classroom action research. The classroom action research design in this study refers to the design model of Kemmis \& McTaggart [16], where each cycle in this study consists of four stages, namely, (1) planning, (2) action, (3) observation, and (4) reflection. The four stages are a cycle or cycle, meaning that after the fourth stage, the first stage returns, and so on. The object of this research is students in the Department of Accounting, State Polytechnic of Malang who take the Marketing Management course with a total of 182 students taken which consisted of 91 students for the experimental class with a Blended Learning model of learning strategy using integrated LMS Moodle with problem-based learning and practice rehearsal pairs, and 91 students for the control class with conventional learning strategies. The data were collected using a questionnaire and conducting a pre-test and post-test. The data analysis technique used is the t-test and univariate analysis of variance with the use of SPSS software.

\section{RESULTS}

\section{A. Description and Test Data on Learning Motivation Results}

The results of the identification of student learning motivation based on questionnaires that have been distributed to students taking Marketing Management courses with conventional models and blended learning modes can be shown in Table I below:

TABLE I. RESULTS IDENTIFICATION OF LEARNING MOTIVATION

\begin{tabular}{|l|l|l|l|}
\hline $\begin{array}{c}\text { Motivation to } \\
\text { learn }\end{array}$ & $\begin{array}{c}\text { Control Class } \\
\text { (Conventional) }\end{array}$ & $\begin{array}{c}\text { Experiment Class } \\
\text { (Blended Learning) }\end{array}$ & \multicolumn{1}{c|}{ Total } \\
\hline Low & 62 & 30 & 92 \\
\hline High & 29 & 61 & 90 \\
\hline Total & 91 & 91 & 182 \\
\hline
\end{tabular}

From the identification results of student learning motivation as shown in Table I above, it can be seen that of the 91 people in the control class (conventional) there are 62 students with low learning motivation and 29 students with high learning motivation. Meanwhile, of the 91 people in the experimental class (blended learning), there were 30 students with low learning motivation and 61 students with high learning motivation.

Comparison of the initial ability (pre-test) and the ability after being given treatment (during the post-test) of the research subjects originating from the pre-test compared with the posttest learning outcomes, then analyzed using the SPSS program to get an idea of how significant the learning outcomes in the student's Marketing Management course between the pre-test and the post-test in the experimental group. In other words, to find out the influence of the provision of learning strategies that have been given to the Marketing Management course. Testing using analysis with paired t-test (paired sample t-test) with the help of the SPSS program is presented in Table II below. 
TABLE II. THE RESULTS OF T TEST FOR THE VALUE OF LEARNING OUTCOMES BETWEEN THE PRE-TEST AND POST-TEST

\begin{tabular}{|c|c|c|c|c|c|c|}
\hline \multicolumn{7}{|c|}{ Paired Samples Statistics } \\
\hline & & Mean & \multicolumn{2}{|c|}{$\mathbf{N}$} & $\begin{array}{c}\text { Std. } \\
\text { Deviation }\end{array}$ & $\begin{array}{c}\text { Std. Erro } \\
\text { Mean }\end{array}$ \\
\hline $\begin{array}{l}\text { Pair } \\
1\end{array}$ & $\begin{array}{c}\text { Value pre- } \\
\text { test } \\
\text { Value post- } \\
\text { test }\end{array}$ & 78.5385 & & 91 & 7.45395 & $\begin{array}{l}.78139 \\
.80252\end{array}$ \\
\hline \multicolumn{7}{|c|}{ Paired Samples Test } \\
\hline & & & $t$ & & Sig. & (2-tailed) \\
\hline $\begin{array}{l}\text { Pair } \\
1\end{array}$ & $\begin{array}{l}\text { Value } \\
\text { (Blended } \\
-\quad \text { Value } \\
\text { (Blended L }\end{array}$ & $\begin{array}{l}\text { post-test } \\
\text { Learning) } \\
\text { Pre-test } \\
\text { earning) }\end{array}$ & 9.896 & 9 & .000 & \\
\hline
\end{tabular}

The results of the SPSS output on paired samples statistics above show that 91 students from the experimental class or with blended learning have an average value of learning outcomes at pretest of 71.45. While the average value of learning outcomes at the post-test was 78.54. The paired samples test output table shows that the average difference in value is 7.088, meaning that the difference in the average value of learning outcomes at the pre-test compared to the post-test is 7.088 (bigger at post-test than pre-test).

Furthermore, to find out the difference in the mean value of learning outcomes at the pre-test and post-test, it is necessary to do statistical testing using the paired t-test (paired-sample ttest). Based on Table I, it shows the paired t- test results for the value of learning outcomes in the experimental group (blended learning) between the pre-test and post-test with a significance value of $0.000(\mathrm{p}<0.05$, reject Ho), which means that there is a significant difference in the value of learning outcomes between at pre-test and post-test, where the value of learning outcomes at post-test is higher than the value of learning outcomes at pre-test. In other words, giving treatment in the form of learning using the blended learning strategy can increase the value of student learning outcomes.

The results of this study are in line with research conducted by Dziuban et al. [17] who found that blended learning has the potential to improve learning outcomes. This situation is partly because blended learning combines several aspects such as web-based instruction, video streaming, synchronous and asynchronous communication, and face-to-face learning [18, 19].

\section{B. Research Hypothesis Testing}

There are three hypotheses tested in this study. Hypothesis testing is carried out when all the analysis requirements are met. The hypotheses tested in this study are as follows:

- There are differences in learning outcomes in marketing management course between groups of students implementing the blended learning strategy and students implementing conventional learning strategies.
- There are differences in learning outcomes in marketing management course between groups of students who have high and low learning motivation.

- There is an interaction between the blended learning strategy and conventional learning strategies with high and low learning motivation on learning outcomes in student marketing management course.

Research hypothesis testing is carried out to prove statistically whether the hypothesis proposed in this study can be accepted or rejected. Hypothesis testing is done by analyzing data on the results of understanding marketing management learning. The results of the calculation of univariate analysis of variance with the help of the SPSS program at a significance value of 0.05 .

Hypothesis testing is done by grouping similar hypotheses to facilitate analysis. Hypothesis 1 is based on the learning strategy used. Hypothesis 2 is based on learning motivation and hypothesis 3 is based on the interaction of the two. In this case, it is tested by analyzing the pairs of the null hypothesis (H0) and the counter hypothesis (H1) as follows:

1) Hypothesis testing 1: The hypothesis tested on the first hypothesis is the null hypothesis (H0): There is no difference in student Marketing Management course outcomes between groups of students implementing blended learning strategies and students implementing conventional learning strategies. Counter hypothesis (H1): There are differences in student marketing management course outcomes between groups of students implementing blended learning strategies and students implementing conventional learning strategies.

Based on the results of the calculations in the Tests of Between-Subjects Effects, it is known that the learning strategy obtained the value of $\mathrm{F}$ count $=12.667$ with a significance value of 0.000 which is below 0.05 alpha. Thus $\mathrm{H} 0$ is rejected, meaning that there is a significant difference in the learning outcomes of Marketing Management between groups of students who learn to use blended learning strategies and groups of students using conventional learning strategies. This is also strengthened by looking at the average value of learning outcomes in the two groups of students, which shows that the average value of learning outcomes for groups of students who learn using the blended learning strategy is 78.54 greater than the average value of the group of students with conventional learning strategies, namely amounting to 71.99. Thus it can be concluded that in general, the learning outcomes of marketing management of students who learn with the blended learning strategy are better than the group of students with conventional learning strategies. The results of this study are supported by the opinion of Collis \& Moonen [20]; Osguthorpe \& Graham [21]; Twigg [22]; and Young [23] which stated that a class with the application of blended learning is more effective than a class that applies a face-to-face approach only. In addition, Thorne [24] also revealed that blended learning is better than conventional learning because blended learning integrates 
innovation and technological advances using online learning and media.

2) Hypothesis testing 2: The second hypothesis tested is the null hypothesis ( $\mathrm{H} 0)$, which is that there is no difference in the learning outcomes of marketing management between groups of students who have high and low learning motivation. The counter hypothesis (H1) is that there are differences in learning outcomes in Marketing Management between groups of students who have high and low learning motivation.

The result of the calculation of univariate analysis of variance with the help of the SPSS program at a significance value of 0.05 indicates that the calculated $F$ score for the learning outcomes of Marketing Management based on learning motivation is 61.703 with a significance value of 0.000 . Because $\mathrm{p}(\mathrm{sig})=0.000$ is smaller than alpha $0.05, \mathrm{H} 0$ is rejected. So, it can be concluded that there is a significant difference in learning outcomes between groups of students who have high learning motivation and students who have low learning motivation, or in other words, students with high learning motivation have better Marketing Management course outcomes than students who have low learning motivation. This result is reinforced by a significant difference in the posttest average score of Marketing Management course outcomes with high learning motivation reaching 80.01 and the post-test average score of Marketing Management course outcomes with low learning motivation of 70.62. The results of this study are supported by Lakonawa et al. [25] who prove that motivation will encourage and guide students to want to learn so that with motivation, students will be able to maintain their enthusiasm for learning until better learning outcomes are achieved.

3) Hypothesis testing 3: The third hypothesis tests the null hypothesis $(\mathrm{H} 0)$ : There is no interaction effect between the blended learning strategy and conventional learning strategies with high and low learning motivation on student Marketing Management course outcomes. Counter hypothesis (H1): There is an influence of the interaction between blended learning strategies and conventional learning strategies with high and low learning motivation on Marketing Management course outcomes.

The results of data calculations to test the hypothesis regarding the effect of the interaction between learning strategies and student learning motivation on Marketing Management course outcomes can be seen by looking at the calculated $\mathrm{F}$ score and the significance score on the learning strategy source and learning motivation in table 4.10. Based on the calculations, it is known that $\mathrm{F}$ count $=4.679$, with a significance value of 0.032 , which is below the alpha value of 0.05 . This means that $\mathrm{HO}$ is rejected, and it can be concluded that there is an interaction effect between the blended learning strategy and the conventional learning strategy with high and low learning motivation on the learning outcomes of Marketing Management. The value of the learning outcomes of Marketing Management with a blended learning strategy with high learning motivation tends to be higher than the value of student marketing management course outcomes with conventional learning strategies with low learning motivation. This result is indicated by the post-test average value for the learning outcomes of Marketing Management students with a blended learning strategy and high learning motivation, which is 80.48 higher than the post-test average value for learning outcomes Marketing Management with a blended learning strategy and motivation learning is low, namely 74.6. As for the post-test average score for student Marketing Management course outcomes with conventional learning strategies and high learning motivation, which is 79.03 higher than the post-test average score for student Marketing Management course outcomes with conventional learning strategies and low learning motivation, namely 68.69.

Therefore, the test results of the differences in the interaction between learning strategies and learning motivation indicate that there is a significant difference in the learning outcomes of Marketing Management between groups of students with high and low blended learning strategies and high and low learning motivation, and groups with conventional learning strategies and high and low motivation to learn. The magnitude of the influence of the blended learning strategy and conventional learning strategies with high and low learning motivation on the student's Marketing Management course outcomes based on the results of the Tests of Between-Subjects Effects shows a coefficient of determination ( $R$ squared) of 0.386 . This can be interpreted as the magnitude of the influence of the blended learning strategy and conventional learning strategies with high and low learning motivation on student Marketing Management course outcomes. This means that $38.6 \%$ of the diversity of student Marketing Management course outcomes is influenced by the blended learning strategy and conventional learning strategies with high and low learning motivation. While the remaining $61.4 \%$ is determined by other factors outside the variables studied.

\section{CONCLUSIONS}

Based on the results of the analysis and testing of research hypotheses, this study can be concluded that there is a significant difference in the learning outcomes of Marketing Management between groups of students who learn using blended learning strategies and groups of students using conventional learning strategies. Besides, there is also a significant difference in learning outcomes between groups of students who have high learning motivation and students who have low learning motivation. The blended learning strategy has influenced a high learning motivation on student Marketing Management course outcomes.

\section{REFERENCES}

[1] R.R. Tjandrawinata, "Industri 4.0: Revolusi industri abad ini dan pengaruhnya pada bidang kesehatan dan bioteknologi", Jurnal Medicinus, Vol 29, Nomor 1, Edisi April. 2016.

[2] P. Pannen, Mempersiapkan SDM Indonesia di era industri 4.0, Jakarta: Kemenristekdikti, 2018. 
[3] A. Sadikin dan N. Hakim, "Pengembangan Media E-Learning Interaktif Dalam Menyongsong Revolusi Industri 4.0 Pada Materi Ekosistem Untuk Siswa SMA", Jurnal Ilmiah Pendidikan Biologi, Vol.5, No. 2, September, hal. 131-138, 2019.

[4] B. Warsita, Teknologi Pembelajaran Landasan dan Aplikasinya, Jakarta: Rineka Cipta, 2008.

[5] A. Sadikin, F. Saudagar, dan F. Muslim, "Development of the Biology Textbook of Process Evaluation and Learning Outcome for Students in Biology Education, University of Jambi”, BIODIK, 4(2), 83-94, 2018.

[6] Rusman, Model-model Pembelajaran (Mengembangkan Profesionalisme Guru), Jakarta: Raja Grafindo Persada, 2014

[7] Sutrisno. Pengantar Pembelajaran Inovatif Berbasis Teknologi Informasi dan Komunikasi, Gaung Persada Press: Jakarta, 2011.

[8] F. Rizkamariana, S. Diana, dan A. R. Wulan, "Penerapan Project Based Learning untuk Melatih Kemampuan Literasi Tumbuhan Abad 21 pada Siswa SMA. Assimilation: Indonesian", Journal of Biology Education, 2(1), 19-23. 2019.

[9] Husamah, Pembelajaran Bauran (Blended Learning), Jakarta: Prestasi Pustaka Jaya, 2014.

[10] K. A. Badeau, "Problem-Based Learning An Educational Method for Nurses in Clinical Practice", Journal For Nurses in Staff Development, Volume 26, Number 6, 2010.

[11] Agus Suprijono, Cooperative Learning Teori \& Aplikasi PAIKEM, Yogyakarta: Pustaka Belajar Celeban Timur, 2013.

[12] N. B. Muthoharoh, "Pengaruh Penggunaan Teknologi Pembelajaran Blended Learning Terhadap Hasil Belajar Menulis Teks Fungsional Pendek Bahasa Inggris”, DEIKSIS, Vol. 09 No.03, hal. 360-373, 2017.

[13] Usman, "Komunikasi Pendidikan Berbasis Blended Learning Dalam Membentuk Kemandirian Belajar", Jurnalisa, Vol. 04, Nomor 1, hal 136-150, 2018.

[14] I. D. Destiana, W. E. Rahayu, N. Mukminah, dan O. Yudianto, "Penerapan Model Blended Learning untuk Meningkatkan Hasil Belajar
Mahasiswa Agroindustri Politeknik Negeri Subang”, EDUFORTECH, Vol. 4 (2), 71-80, 2019.

[15] E. C. Prawoto \& Pramulia, "Pembelajaran Sastra Berbasis Blended Learning”, Efektor, Vol. 6, Issue 1, pp. 37 - 42, 2019.

[16] S. Kemmis \& R. McTaggart, The Action Research Planner, 3rd edn. Deakin University Press, Geelong, 1988.

[17] Charles D. Dziuban, Joel L. Hartman, Patsy D. Moskal, "Blended Learning”, Research Bulletin. Volume 2004, Issue 7, March 30, 2004.

[18] A. H. Ahmed, Nabeel Al-Huwail, and Salah Al-Sharhan, "Blended elearning design : Discussion of cultural issues", Journal of Cyber Society and Education, 17-32, 2008.

[19] Tina L. Salata, "Increasing a Sense of Place Using Blended Online and On Site Learning", Journal of Sustainability Education, Vol. 12, February, 2017.

[20] Collis, B. \& Moonen, J. (2001). Flexible Learning in A Digital World: Experiences and Expectations. London: Kogan-Page.

[21] R. Osguthorpe \& R. Graham, "Blended Learning Environments: Definitions and Directions", The Quarterly Review of Distance Education, 4(3), pp. 227-234, 2003.

[22] C. Twigg, "Improving Learning and Reducing Costs: New Models for Online Learning", Educause Review, 38(5), pp. 28-38, 2003.

[23] J. R. Young, "Hybrid Teaching Seeks to End the Divide Between Traditional and Online Instruction", The Chronicle of Higher Education, 48 (28), A33-A34, 2002.

[24] K. Thorne, Blended learning: How to integrate online and traditional learning, London: Kogan Page Publishers, 2003.

[25] P. Lakonawa, A. Benawa, M. M. Bali, "Pengaruh Kemampuan Dosen dalam Mengelola Kelas dan Model Pembelajaran Terhadap Motivasi Belajar Mahasiswa Binus University", HUMANIORA. 5 (1), pp. 316 323, 2014. 